\title{
VOLLEYBALL FUNDAMENTAL MOVEMENT LEARNING MODEL IN PRIMARY SCHOOL
}

\author{
Samsudin $^{1 \mathrm{AB}}$, Iwan Setiawan ${ }^{1 \mathrm{BC}}$, Muhammad Syamsul Taufik ${ }^{2 \mathrm{CD}}$, Soleh Solahuddin ${ }^{3 \mathrm{BDE}}$ \\ ${ }^{1}$ Universitas Negeri Jakarta \\ ${ }^{2}$ University of Suryakancana \\ ${ }^{3}$ University of Sriwijaya
}

Authors' Contribution: A - Study design; B - Data collection; C - Statistical analysis; D - Manuscript Preparation; E - Funds Collection

Corresponding Author: Samsudin, E-mail: samsudin@unj.ac.id

Accepted for Publication: August 12, 2021

Published: September 25, 2021

DOI: 10.17309/tmfv.2021.3.02

\begin{abstract}
The study purpose. This study aims to develop a volleyball fundamental movement learning model with a gamecentered approach and test its effectiveness in improving the volleyball learning outcomes of elementary school students

Materials and methods. The research method used is research and development (R\&D) which adopts the10 steps of Borg and Gall R\&D model. The data analysis techniques used in this study were qualitative and quantitative. This study used a pretest-posttest control group design to determine the initial abilities of the experimental and the control group $(\mathrm{n}=40)$. The significance test of the learning model effectiveness used a t-test. Normality test was carried out before the data analysis on the results of the experimental group and the control group improvement in the fundamental movement of volleyball with the significance level $=0.05$.

Results. The results of this study indicate a significant improvement for the experimental group data (0.97) and the control group data (0.42). Because the significance value of the two groups is more than 0.05 , the overall data for the study group is normally distributed. The learning model effectiveness test results show the value of t-count -71.065. Conclusions. The fundamental movement improvement of the experimental group is higher or more effective than that of the control group. So it can be concluded that the volleyball fundamental movement learning model with a game-centered approach is effective and efficient to be given to elementary school students.
\end{abstract}

Keywords: learning model, fundamental movement, volleyball.

\section{Introduction}

Physical education (PE) is a learning process through physical activities designed to improve physical fitness, develop motor skills, knowledge and behavior for healthy and active living, sportsmanship, and emotional intelligence. PE promotes physical activity which are linked to physical (Griffo et al., 2020) and mental benefits (Haverkamp et al., 2020; Singh et al., 2019). PE intend to provide beneficial effects in supporting academic achievements, fostering non-cognitive skills, improving motor skills, encouraging physical activity, and improving health (Knaus et al., 2020). The learning environment is carefully regulated to foster the growth and development of all students, physical, psychomotor, cognitive, and affective domains (Arfa et al., 2020). Volleyball in

(C) Samsudin, Setiawan, I., Taufik, M.S., Solahuddin, S., 2021.
PE learning is one of the main materials for big ball games (Jati et al., 2019), which has a strategic role in promoting the healthy habits of students. Volleyball has a positive effect on physical aspects so that it can be applied to students on account of it easily being applicable, and having low injury risk (Sozen, 2012). To achieve good learning outcomes in volleyball, especially basic volleyball techniques, teachers must find effective ways to teach the fundamental movements so that learning outcomes in volleyball learning are expected to be successful (Makadada et al., 2019).

Most elementary students are beginners in Physical and Sports Activities (PSA) because they do not know how the rules are implemented, even though it has been explained by the teacher in previous classes. This finding assumes that there are facts that hinder the volleyball learning in normal elementary school classroom situations. These facts explain that there are problems in elementary school volleyball learning that must be highlighted (Basile et al., 2019). Fur- 
thermore, these facts can be found in many regions, including Indonesia.

The learning method chosen by the teacher must consider the characteristics of students' development. Some of the characteristics of elementary school students are: students love to play; students love to move; students love to work in group; students love to feel, do, and demonstrate directly. Students must be taught to improve their technical execution through practical assignments for the development of skills and understanding of the meaning of techniques obtained when contextualized in the play. This is important because students learn in a play-like context that allows the best opportunity to transfer their skills (Morales-belando et al., 2018). PE teachers can use game-centered approach so that the PE learning process can reflect DAP (Developmentally Appropriate Practice) according to the development stage approach, which means that learning tasks must pay attention to the changes in students' abilities or conditions and help encouraging these changes (Hambali, 2018). Moreover, the approach in the learning process of the volleyball fundamental movements must be able to make the players (especially beginners) happy and provide variations so that the players do not easily get bored (Islam, 2019).

Several studies related to volleyball learning models have been conducted before, but none has developed a volleyball fundamental movement learning model with a gamecentered approach. Previous studies focused on volleyball passing (Ajayati, 2017; Syafrizar \& Hermanzoni, 2020) and serving model (Budiarti et al., 2019; Islam, 2019), while some others focused on cooperative learning (Nieves et al., 2019; Maya Ningrum et al., 2020) and instructional and representative criteria (Hutagalung et al., 2020). In this study, the items of variations in the learning model include all the fundamental movements of volleyball. All activities are developed based on the characteristics of elementary students, suitable facilities and infrastructure, and interesting methods. Activities are developed using game-centered principles, so they become more interesting and fun. The product developed has internalized volleyball learning activities with active student learning methods..

\section{Materials and methods}

The research method used in this study is research and development (R\&D) which adopts the 10 steps of Borg and Gall $\mathrm{R} \& \mathrm{D}$ model. The data analysis techniques used in this study were qualitative and quantitative. This study used a pretestposttest control group design to determine the initial abilities of the experimental and control group. 40 students participated in the effectiveness test which separated into experimental and control group. The design of the model development in this study will be carried out in several stages as follows (fig. 1).

$\mathrm{N}$-Gain test was used to analyze the effect of the learning model, while paired sample correlation and the paired sample test was respectively used to analyze the effectiveness of the model and the significancy of students after being given the volleyball learning (fig. 1, tabl. 1).

\section{Results}

$\mathrm{N}$-Gain test was carried out to find out the improvement of students which devided in to experiment group which was given the volleyball fundamental movement learning model and control group which was given the usual volleyball learning model. The following table contains the results of the N-Gain test (tabl. 2).

Based on the results above, it can be concluded that the improvement of the $\mathrm{N}$-Gain score in the experimental group after being given treatment reaches the high category, while in the control group it reaches the medium category.

Based on the results on the table above, the coefficient of the volleyball fundamental movement learning model in Elementary School before and after being given the volleyball learning model is 0.275 with a p-value of $0.00<0.05$. So in can be stated that the learning model is effective to be applied (tabl. 4).

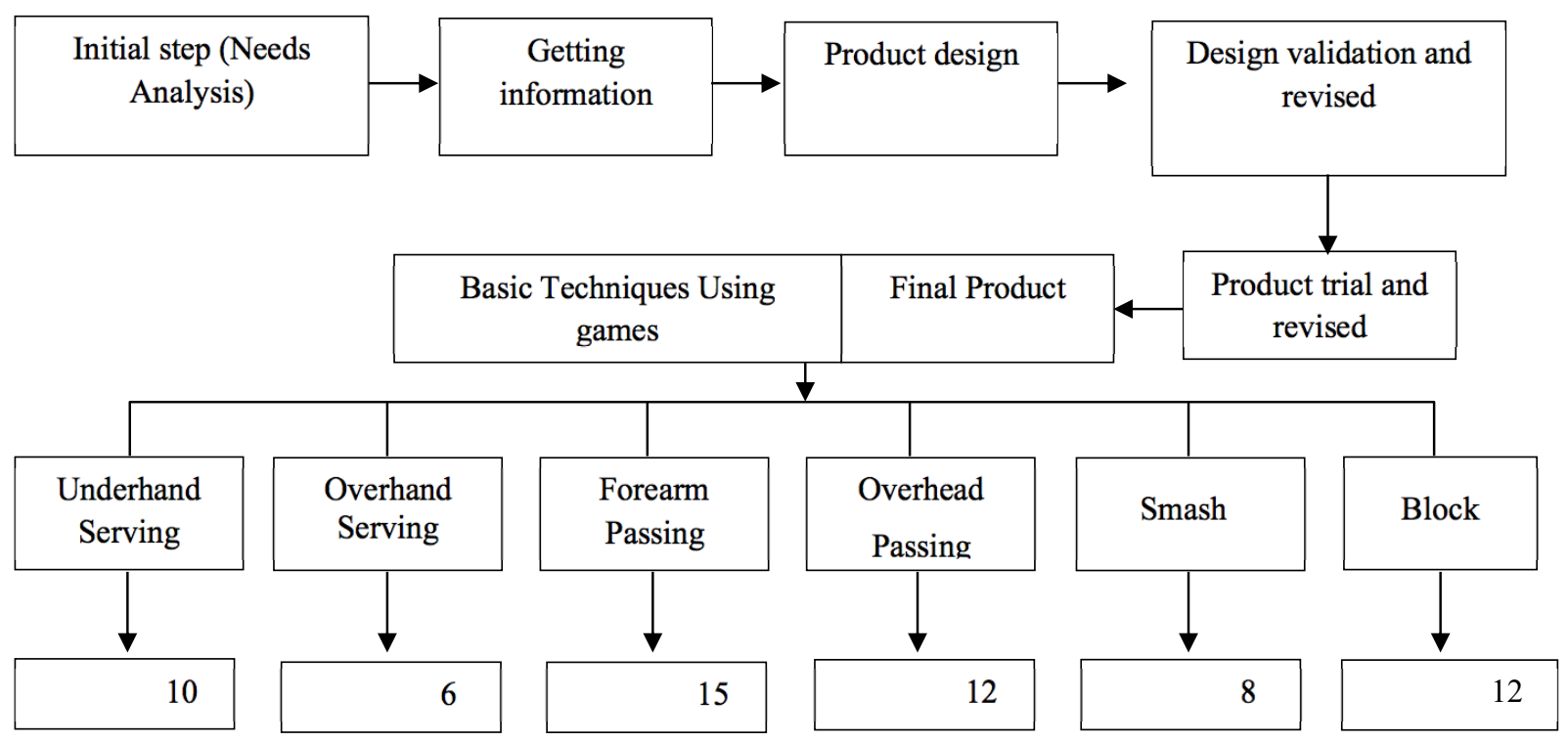

Fig. 1. Steps of R\&D Model 
Table 1. Variation of Volleyball basic techniques with the types of games

\begin{tabular}{|c|c|c|}
\hline Volleyball Basic & & f Games \\
\hline Underhand Serving & 1. Throw Without Kick & 6. Obstacle Blow \\
\hline & 2. Throw Without Kick Pair & 7. Cardboard Hurdle Blows \\
\hline & 3. Shadow Blows & 8. Plastic Rope Hurdle Blows \\
\hline & 4. Lightning Punch & 9. Shadow Barrier Blows \\
\hline & 5. Face Punch Without Obstacles & 10. Ninja Hatori's Punch \\
\hline Overhand Serving & 1. Service blow over & 4. Flying Balloon Blows \\
\hline & 2. One-Handed Punch & 5. Blow the ball to the wall \\
\hline & 3. Happy Ball Punch & 6. Target Punch \\
\hline Forearm Passing & 1. Controlled Throw in Place & 9. Chase Throw Catch Chase the Ball \\
\hline & 2. Beautifully Controlled Throw & 10. Ball Catch Aisle \\
\hline & 3. Chasing the Rope & 11. Parallel Ball Catcher Hallway \\
\hline & 4. Chase the ball & 12. Estapet Ball Catcher Hallway \\
\hline & 5. Pairing Passing & 13. Obstacle course \\
\hline & 6. Passing the Ball in Place & 14. Right Target Circle \\
\hline & 7. Beautiful Forward Ball Passing & 15. Obstacles to Ball Cooperation \\
\hline & 8. Throwing the horses & \\
\hline Overhead Passing & 1. Throw Ball Catch & 7. Beautiful Forward Horses \\
\hline & 2. Happy Throws & 8. Throwback and forth Hator \\
\hline & 3. Passing Up in Place & 9. Throw Snake Catch \\
\hline & 4. Passing Up Fun & 10. Throw Catch Tsubasa \\
\hline & 5. Joyful Rope & 11. Throw a Falling Ball \\
\hline & 6. Joyful Rope Estapet & 12. Clock Basket \\
\hline Smash & 1. Target Throw & 5. Colourful Steps \\
\hline & 2. Empty Hand Kick & 6. Run for your dreams \\
\hline & 3. Power Kick & 7. Color Ball Step Cardboard \\
\hline & 4. Hula Hup Hurdles & 8. Hanging Ball Cardboard Punch \\
\hline Block & 1. Jumping on the spot & 7. Throw of Sacred View \\
\hline & 2. Clap Couple & 8. Happy Ball Throws \\
\hline & 3. Couple Jumps & 9. Beautiful Cardboard Throw \\
\hline & 4. Sweet sit & 10. Like Cardboard \\
\hline & 5. Beautiful hand & 11. Hip-hip Carton \\
\hline & 6. Knee Sitting Throws & 12. Happy Circle (Tiktok) \\
\hline
\end{tabular}

Table 2. Results of the N-Gain Score Test

\begin{tabular}{ccccc}
\hline \multirow{2}{*}{$\mathbf{N}$} & \multicolumn{2}{c}{ Experiment Group } & \multicolumn{2}{c}{ Control Group } \\
\cline { 2 - 5 } & Gain score & Information & Gain score & Information \\
\hline 40 & 0.97 & High & 0.42 & Medium \\
\hline
\end{tabular}

Table 3. Paired Samples Correlations

\begin{tabular}{lcccc}
\hline & & N & Correlation & Sig. \\
\hline Pair 1 & Pre \& Post & 40 & .275 & .033 \\
\hline
\end{tabular}

In the difference significance test with SPSS 21, the results of $\mathrm{t}$-count $=-71.065, \mathrm{db}=39$ and $\mathrm{p}$-value $=0.00<0.05$, which means that there was a significant difference in the volleyball fundamental movement skills of elementary school students before and after being given the learning (tabl. 4).

\section{Discussion}

\section{Product Design}

The results of the design validation that carried out in this research and development produced 63 models of game- based fundamentall volleyball fundametal movement, consisting of 10 models of underhand serving, 6 models of overhand serving, 15 models of forearm passing, 12 models of overhead pasing, 8 models of smash, and 12 models of block. Previously, the initial design was planned and validated so that it can produce development products in the form of 63 learning models that are ready to be implemented. According to (Huang et al., 2020), the basic stage of research and development activities aims to analyze the physical structure and various object relationships through experimental analysis or theoretical research. All game models were designed according to the volleyball fundamental movement through in-depth need analysis, theoretical study, and planning.

2. Operational Product Revision (Revision of Large Scale Trial Results)

The main field testing that have been carried out by researchers have resulted in several notes to be used as material for correction and evaluation. Some of the notes collected by the researcher are as follows:

- When students did all the volleyball fundamental movement models, it took a large area because students can make movements freely. 
Table 4. Paired Samples Test

\begin{tabular}{|c|c|c|c|c|c|c|c|c|c|}
\hline & & \multicolumn{5}{|c|}{ Paired Differences } & \multirow{3}{*}{$\mathbf{t}$} & \multirow{3}{*}{ df } & \multirow{3}{*}{$\begin{array}{c}\text { Sig. } \\
\text { (2-tailed) }\end{array}$} \\
\hline & & \multirow[t]{2}{*}{ Mean } & \multirow{2}{*}{$\begin{array}{c}\text { Std. } \\
\text { Deviation }\end{array}$} & \multirow{2}{*}{$\begin{array}{l}\text { Std. Error } \\
\text { Mean }\end{array}$} & \multicolumn{2}{|c|}{$\begin{array}{l}\text { 95\% Confidence Interval of } \\
\text { the Difference }\end{array}$} & & & \\
\hline & & & & & Lower & Upper & & & \\
\hline Pair 1 & Pre - Post & -11.80000 & 1.28617 & .16604 & -12.13225 & -11.46775 & -71.065 & 39 & .000 \\
\hline
\end{tabular}

- The safety factor is very important in the learning process.

- There are several models that need to be considered; when students did a running motion followed by jumping upwards, some students did it in the wrong timing.

- Discipline must always be considered, so that unwanted results do not occur.

The main field testing led to the extent to which the learning process can take place. Based on the notes, suggestions, and findings on the main product field test above, it can be concluded that all the fundamental movement learning models for volleyball are feasible and can be used in physical education learning in elementary schools. Bisagno and Morra (2018) stated that students need attentional resources to learn volleyball gesture. The play approach was used to improve the interest and attention of the students. By learning the fundamental volleyball movements through the play approach, it can be continued in the effectiveness test, in order to determine the extent to which this development product achieves the goal of improving the basic volleyball learning outcomes of elementary school students.

\section{Operational Field Testing / Effectiveness Test}

At this stage, the researcher used a volleyball basic movement skill instrument that the researcher made and has been validated. In this effectiveness test using subjects as many as 40 students of Bekasi 27 State Elementary School. The results of the assessment of 40 students on the effectiveness of volleyball fundamental movement learning model development through the play approach for elementary school students. Based on the results on effectiveness test, the coefficient of the volleyball fundamental movement learning model shows that the learning model is effective to be applied in elementary school. Furthermore, a paired sample test was carried out and the results show that there was a significant difference in the volleyball fundamental movement skills of elementary school students before and after being given the learning. Based on this information, it can be stated that the volleyball fundamental movement learning model that was developed is effective and can improve volleyball fundametal movement of elementary schools students.

\section{Final Product Revision}

After the main field test and effectiveness test were carried out, the volleyball fundamental movement learning model through the play approach became the final product. The final model is the result of a large group trial, which meets the eligibility standards for use. Volleyball is a sport with a relatively large range, so once the action is not standard, it is very easy to cause damage to the player (Zhang \& Zhong, 2021). The final model of the fundamental movement learning model for volleyball through the play approach for elementary school children is packed in the form of a book.

\section{Dissemination and Implementation}

This step is the final stage in research on the development of a fundamental movement learning model for vol- leyball through a play approach. At this stage, the product was disseminated and implemented in several elementary schools in Jakarta, Indonesia.

\section{Conclusion}

According to this research and development, it can be concluded that the product in the form of a volleyball fundamental movement learning model was designed based on volleyball fundamental movements with in-depth need analysis, theoretical study, and planning. The results of the design validation that carried out in this research and development produced game-based 63 models.

The volleyball fundamental movement model with play approach, in a complex manner, is very suitable to be used for elementary school students in the volleyball learning. The volleyball fundamental movement model was packed in a book to make it easier for teachers to use or apply the learning materials and improve the variety and effectiveness of the ongoing teaching and learning process. The learning model was empirically proven effective to be applied in elementary school.

\section{Acknowledgement}

We are grateful for the support of Jakarta State University. We are also grateful for the support from the campus department and the extended family of the Jakarta State University Physical Education Study Program.

\section{Conflict of interest}

No potential conflict of interest was reported by the authors.

\section{References}

Griffo, J. M., Hodges-Kulinna, P., Marttinen, R. H. J., \& Battistella, S. (2020). A systematic review of integrative practices in physical education (2009-2018). International Journal of Educational Research, 104, 101689. https://doi.org/10.1016/j.ijer.2020.101689

Haverkamp, B. F., Wiersma, R., Vertessen, K., van Ewijk, H., Oosterlaan, J., \& Hartman, E. (2020). Effects of physical activity interventions on cognitive outcomes and academic performance in adolescents and young adults: A meta-analysis. Journal of Sports Sciences, 38(23), 26372660. https://doi.org/10.1080/02640414.2020.1794763

Singh, A. S., Saliasi, E., Van Den Berg, V., Uijtdewilligen, L., De Groot, R. H. M., Jolles, J., Andersen, L. B., Bailey, R., Chang, Y. K., Diamond, A., Ericsson, I., Etnier, J. L., Fedewa, A. L., Hillman, C. H., McMorris, T., Pesce, C., Pühse, U., Tomporowski, P. D., \& Chinapaw, M. J. M. (2019). Effects of physical activity interventions on 
cognitive and academic performance in children and adolescents: A novel combination of a systematic review and recommendations from an expert panel. British Journal of Sports Medicine, 53(10), 640-647. https://doi.org/10.1136/bjsports-2017-098136

Knaus, M. C., Lechner, M., \& Reimers, A. K. (2020). For better or worse? - The effects of physical education on child development. Labour Economics, 67, 101904. https://doi.org/10.1016/j.labeco.2020.101904

Arfa, M., Akhmad, I., \& Nugraha, T. (2020). Different Effects Between Cooperative and Sociometric Learning on Lower Passing Learning Outcomes in Volleyball Games of Grade VIII Students at SMP Negeri 14 Medan. 384(Aisteel), 475-478. https://doi.org/10.2991/aisteel-19.2019.105

Jati, A. W. K., Hidayah, T., \& Wahyudi, A. (2019). The Implementation of Team Games Tournament Learning Model to The Volleyball Play Technique in Randudongkal Junior High School. Journal of Physical Education and Sports, 8(4), 32-37. Retrieved from https://journal.unnes. ac.id/sju/index.php/jpes/article/view/31559

Sozen, H. (2012). The Effect of Volleyball Training on the Physical Fitness of High School Students. Procedia Social and Behavioral Sciences, 46, 1455-1460. https://doi.org/10.1016/j.sbspro.2012.05.320

Fredrik Alfrets Makadada, Christianti Anggraini Motto, \& Nolfie Piri. (2019). The Improvement of Learning Outcomes on Bump Pass of Volleyball (The Application of Difficulty Level Approach on Students of Sport Coaching Education Department in FIK UNIMA). Britain International of Linguistics Arts and Education (BIoLAE) Journal, 1(2), 119-134. https://doi.org/10.33258/biolae.v1i2.80

Basile, A. D., M, O. B., Kossivi, A., \& Anne-marie, G. (2019). The problem of learning volleyball in second form: A study of two cases of teaching in Za-Tanta in Benin. 6(5), 200-210.

Morales-Belando, M. T., Calderón, A., \& Arias-Estero, J. L. (2018). Improvement in game performance and adherence after an aligned TGfU floorball unit in physical education. Physical Education and Sport Pedagogy, 23(6), 657-671. https://doi.org/10.1080/17408989.2018.1530747

Hambali, S. (2018). Playing Approach of Overhead Passing Learning in Volleyball Games. Journal of Teaching Physical Education in Elementary School, 2(1), 46-52.

Islam, R. W.H., Hernawan, \& Setiakarnawijaya, Ya. (2019). Model of Volleyball Smash Skills Exercise Model for High
School Beginners Athletes. Journal of Physical Education, Sport, Health and Recreation, 8(3), 134-138.

Ajayati, T. (2017). The Learning Model of Forearm Passing In Volleyball for Junior High School. JETL (Journal Of Education, Teaching and Learning), 2(2), 218. https://doi.org/10.26737/jetl.v2i2.289

Syafrizar \& Hermanzoni. (2020). Development of Training Model Under Passing Skill of Volleyball Athletes. Proceedings of the 1st Progress in Social Science, Humanities and Education Research Symposium (PSSHERS 2019), 947-950.

https://doi.org/10.2991/assehr.k.200824.210

Budiarti, W. W., Hanif, A. S., \& Samsudin, S. (2019). Volleyball Smash Learning Model for Middle School Students. Budapest International Research and Critics in Linguistics and Education (BirLE) Journal, 2(4), 238-244. https://doi.org/10.33258/birle.v2i4.512

Nieves, A. M., Oliver, L. E., \& Oliver, L. E. (2019). Introducing a TGfU Mini-volleyball Unit. Journal of Physical Education, Recreation \& Dance, 90(9), 56-60. https://doi.org/10.1080/07303084.2019.1658499

Maya Ningrum, D. T., Rizkei Kurniawan, \& Mahyudi, Y. V. (2019). The Effect of Cooperative Learning and Self Confidence on Service Volleyball At SMPN 4 Negara. JIPES - Journal of Indonesian Physical Education and Sport, 5(1), 63-68. Retrieved from http://journal.unj.ac.id/ unj/index.php/jipes/article/view/14657

Hutagalung, E. A., Sunarno, A., \& Hasibuan, S. (2020). Development of Volleyball Service Learning Model for Seventh Grade Students. 1st Development of Volleyball Service Learning Model for Seventh Grade Students. Proceedings of the 1st Unimed International Conference on Sport Science (UnICoSS 2019), 198-200. https://doi.org/10.2991/ahsr.k.200305.055

Huang, J., Wang, L., Wang, D., \& Lei, H. (2020). Decreasing China's carbon intensity through research and development activities. Environmental Research, 190, 109947. https://doi.org/10.1016/j.envres.2020.109947

Bisagno, E., \& Morra, S. (2018). How do we learn to "kill" in volleyball?: The role of working memory capacity and expertise in volleyball motor learning. Journal of Experimental Child Psychology, 167, 128-145. https://doi.org/10.1016/j.jecp.2017.10.008

Zhang, G., \& Zhong, L. (2021). Research on volleyball action standardization based on 3D dynamic model. Alexandria Engineering Journal, 60(4), 4131-4138. https://doi.org/10.1016/j.aej.2021.02.035 


\title{
МОДЕЛЬ НАВЧАННЯ ОСНОВНИХ РУХІВ ВОЛЕЙБОЛУ В ПОЧАТКОВІЙ ШКОЛІ
}

\author{
Самсудін $^{1 \mathrm{AB}}$, Іван Сетяван ${ }^{1 \mathrm{BC}}$, Мухаммед Сямсул Тауфік ${ }^{2 \mathrm{CD}}$, \\ Солех Солахуддін ${ }^{3 \mathrm{BDE}}$
}

'Університет Негері Джакарта

${ }^{2}$ Університет Сурьяканчана

${ }^{3}$ Університет Шрівіджая

Авторський вклад: А - дизайн дослідження; В - збір даних; C - статаналіз; D - підготовка рукопису; Е - збір коштів

Реферат. Стаття: 6 с., 4 табл., 21 джерело.

Мета дослідження. Дане дослідження має за мету розробити модель навчання основних рухів волейболу із застосуванням ігрового підходу та перевірити ії ефективність у поліпшенні результатів навчання волейболу учнів початкової школи.

Матеріали та методи. У дослідженні використано метод дослідження та розробки $(\mathrm{R} \& \mathrm{D})$, який грунтується на 10 кроках моделі R\&D Борга та Галла. Застосовано якісні та кількісні методи аналізу даних. Використовувався план групового контролю до і після тестування для визначення початкових здібностей експериментальної та контрольної груп ( $\mathrm{n}=40)$. Значущість ефективності моделі навчання перевірялася за допомогою t-критерію. Тест на нормальність розподілу проводився перед аналізом результатів поліпшення основних рухів волейболу експериментальної та контрольної груп з рівнем значущості $=0,05$.
Результати. Результати дослідження вказують на значне поліпшення даних експериментальної $(0,97)$ та контрольної груп $(0,42)$. Оскільки рівень значущості двох груп перевищує 0,05, загальні дані для досліджуваної групи розподілені нормально. Результати тестування ефективності моделі навчання показують значення t-count -71,065.

Висновки. Поліпшення основних рухів у експериментальній групі вище або більш результативне, ніж у контрольній групі. Таким чином, можна зробити висновок, що модель навчання основних рухів волейболу із застосуванням ігрового підходу є ефективною та дієвою для учнів початкової школи.

Ключові слова: модель навчання, фундаментальний рух, волейбол.

\section{Information about the authors:}

Samsudin: samsudin@unj.ac.id; https://orcid.org/0000-0003-1565-4202; Faculty of Sport Science, Universitas Negeri Jakarta, Rawamangun, 13220, Jakarta, Indonesia.

Setiawan, I.: iwansetiawan@unj.ac.id; https://orcid.org/0000-0003-4655-3404; Faculty of Sport Science, Universitas Negeri Jakarta, Rawamangun, 13220, Jakarta, Indonesia.

Taufik, M.S.: syamsul@unsur.ac.id; https://orcid.org/0000-0001-5936-515X; Faculty of Teacher Training and Education, Physical Education, Health and Recreation, University of Suryakancana, Cianjur, Jawa Barat, 43216, Indonesia.

Solahuddin, S.: solehsolahuddin@fkip.unsri.ac.id; https://orcid.org/0000-0001-8959-3073; Faculty of Teacher Training and Education, Physical Education, Health and Recreation, University of Sriwijaya, Palembang, Sumatera Selatan, 30128, Indonesia.

Cite this article as: Samsudin, Setiawan, I., Taufik, M.S., \& Solahuddin, S. (2021). Volleyball Fundamental Movement Learning Model in Primary School. Teoriâ ta Metodika Fizičnogo Vihovannâ, 21(2), 194-199.

https://doi.org/10.17309/tmfv.2021.3.02

Received: 14.06.2021. Accepted: 12.08.2021. Published: 25.09.2021

This work is licensed under a Creative Commons Attribution 4.0 International License (http://creativecommons.org/licenses/by/4.0). 